
2021.

Received: 6 November 2021.

Accepted: 9 November 2021.

\title{
NOTES ON 'CONTEMPORARY BILINGUALISM, LLANITO AND LANGUAGE POLICY IN GIBRALTAR: A STUDY' WITH A PRESENT-DAY VIEW OF LINGUISTIC CHALLENGES.
}

DAVID CHEVASCO ${ }^{1}$

\author{
I. MINORITY L ANGUAGES AND IDENTITY - II. LLANITO - IN WHAT \\ CONTEXTS? - III. THE FUTURE OF BILINGUALISM IN GIBRALTAR
}

\begin{abstract}
Contemporary Bilingualism, Llanito and Language Policy in Gibraltar: A Study highlights some important language issues in Gibraltar and other multilingual communities, such as minority languages, their survival, and the simultaneous preservation of local identity and proficiency in majority languages. Brexit conversations regarding Gibraltar, and to a lesser extent Covid-19 restrictions, may have an effect on language and linguistic sensibilities on the Rock, by either allowing a greater movement of people and languages, or by limiting them. The status of English as one of the EU's official languages may be called into question post-Brexit. Gibraltar's language policy is unlikely to change to a bilingual one if local identity is threatened. It is ultimately an individual choice of whether to preserve bilingualism among family and friends, or to consolidate native monolingualism and the image of Britishness.
\end{abstract}

KEYWORDS: minority languages, Llanito, Brexit, identity, bilingualism.

\section{NOTAS SOBRE 'CONTEMPORARY BILINGUALISM, LLANITO AND LANGUAGE POLICY IN GIBRALTAR: A STUDY', CON UNA PERSPECTIVA ACTUAL DE LOS DESAFIOS LINGÜÍSTICOS}

RESUMEN: El libro Contemporary Bilingualism, Llanito and Language Policy in Gibraltar: A Study destaca problemas lingüísticos presentes en Gibraltar al igual que en otras comunidades multilingües, como son lenguas minoritarias, su supervivencia, y la preservación simultánea de tanto

\footnotetext{
${ }^{1}$ David Chevasco was born in Gibraltar in 1981. As a bilingual with a keen interest in languages and literature, he studied English language and literature at The University of Reading (UK), graduating in 2002, and attained his CELTA (Cambridge Certificate of English Language Teaching) in Rome, Italy in 2003. In 2017 he completed an MA in TESOL with University College London. He has taught English as a second or foreign language in Italy, the UK, Spain, where he was Director of Studies at the (renamed) 'New English Centre' in Malaga, and Japan since 2015. He is currently a full-time lecturer at Chiba University, Japan, specialising in Bilingualism and learner motivation.
} 
la identidad local como el dominio de las lenguas mayoritarias. Las negociaciones de Brexit sobre Gibraltar y, en menor medida, las restricciones de Covid-19, pueden tener efectos sobre el habla y la sensibilidad lingüística local, ya sea permitir un mayor movimiento de personas e idiomas, o limitarlos a ciertos grupos. De la misma manera el Brexit puede poner en duda la condición del inglés como lengua oficial de la UE. No obstante, es poco probable que la política cambie para incorporar el castellano si la identidad de pueblo se ve amenazada, por lo que, en última instancia, se trata de la elección del individuo si preservar el bilingüismo entre familiares y amigos, o consolidar el monolingüismo nativo y la imagen del ciudadano británico de Gibraltar.

PALABRAS CLAVE: idiomas minoritarios, Llanito, Brexit, identidad, bilingüismo.

Published in late 2019, coinciding with the Covid-19 outbreak Contemporary Bilingualism, Llanito and Language Policy in Gibraltar: A Study ${ }^{2}$ (Contemporary) is a mixed methods study examining young Gibraltarian adults' attitudes towards each of the three language codes: English, Spanish and Llanito, and analyses their uses and practicality in the Gibraltar of the $21^{\text {st }}$ century. In this brief article, I would like to highlight some of the salient points from the study published by Cádiz University Press and add some personal reflections on the relevance of linguistic awareness, as we enter a new reality in Gibraltar dominated by the effects of Brexit and perhaps Covid-19.

\section{MINORITY LANGUAGES AND IDENTITY}

Contemporary argues that while Spanish is the second most spoken language in the world, it is being reduced to the category of minority language among the Gibraltarian population and would require state support if Gibraltarians are to remain literate in standard Spanish ${ }^{3}$. There appears to be a clear generational divide between either language preference or proficiency in either English, Spanish or Llanito in Gibraltar. There is no good reason why parents should act as interpreters between grandparents and grandchildren who have not been taught $\mathrm{Spanish}^{4}$, if they all live in the same community.

On the flip side, the study also refers to the reasoning behind enabling majority languages within a community. Contemporary refers to May's ${ }^{5}$

${ }^{2}$ Chevasco, D., Contemporary Bilingualism, Llanito and Language Policy in Gibraltar: A Study, UCAUniversidad de Cádiz, 2019.

${ }^{3}$ Ibidem.

${ }^{4}$ Levey, D., Language Change and Variation in Gibraltar, John Benjamins Publishing, 2008.

${ }^{5}$ MAY, S., "Language Rights: Moving the Debate Forward", Journal of Sociolinguistics 9, 3, 2005: 319-47. 
arguments about how the irrevocable quality of history, the reality of recent human mobility and individual job prospects are factors that support favouring majority languages. Nonetheless, the study contradicts purist beliefs that bilingualism or language mixing contribute to decreased proficiency or laziness within certain language groups. References to studies by Sayer ${ }^{6}$ and Peñalva ${ }^{7}$ highlight the inborn grammatical awareness of native Spanglish bilinguals in the US and signal the maintenance of Spanglish as a necessary feature of a community's identity. Chevasco hints that losing the Spanish language in Gibraltar may also affect local identity.

A community's sense of identity is a powerful precursor to how most people will choose to speak their language, especially among other community members. The publication draws comparisons between Gibraltar and Mauritius, which, much like Llanito, has its own code-switching language form made up of a variety of languages ${ }^{8}$. It also compares Gibraltar and Cameroon, where local people might be laughed at by their peers for pronouncing words with an 'excessive' British accent, and not in their own Cameroonian English ${ }^{9}$. In this sense, Contemporary links identity with the idea of feeling comfortable when communicating, and analyses how comfortable the participants feel using each language in a variety of different settings.

\section{LLANITO - IN WHAT CONTEXTS?}

Despite being born out of necessity in the 1700s so that merchants in Gibraltar of different backgrounds could communicate in a common tongue, circumventing the potential disadvantages of emulating the English of the coloniser, or the Spanish of the aggressive neighbour, Llanito has continually managed, to a greater or lesser degree, to feature in exchanges between locals

${ }^{6}$ SAYER, P., "Demystifying Language Mixing: Spanglish in School", Journal of Latinos and Education. 7, 2, 2008: 94-112.

${ }^{7}$ Peñalva, S. L., "An Ethnographic Portrait of Translingual/Transcultural Navigation among Immigrant Children and Youth: Voices during Sunday School at a Latino Church", Journal of Multilingual and Multicultural Development. 2016: 1-15.

8 Auckle, T. and Barnes, L. "Code-Switching, Language Mixing and Fused Lects: Emerging Trends in Multilingual Mauritius", Language Matters 42, 1, 2011: 104-25.

${ }^{9}$ Anchimbe, E. A., Structural and Sociolinguistic Perspectives on Indigenisation. Dordrecht: Springer Netherlands. 2014. 
to the present day. While lexical elements from Hebrew, Arabic, Genoese Italian and others may have faded with time to give way to a more binary codeswitching variety of British English and Andalusian Spanish, participants in the study validated Llanito as the language of choice with a best friend, or the language used in online posts on social networking sites. ${ }^{10}$

It is telling statistic that Llanito emerged as the most appropriate language form when talking to a best friend or immediate family member, which are arguably situations in which people communicate most comfortably. Not unlike how Liverpudlians, Londoners, Malagueños, or people almost anywhere in the world will perhaps switch to a more casual accent with people from their same community, possibly speaking with lexis uncommon in other parts of the country or region, Gibraltarians will code-switch, with wordlevel pronunciation perhaps fluctuating between Standard British English for English words, to Andalusian Spanish for Spanish words. Sentence intonation will usually also be found somewhere between these two poles, depending on the individual and their immediate environment, although like much of the English-speaking world, North American media and communications may be having an influence on Gibraltarian English intonation.

An interesting finding that surfaced in Contemporary was the popularity of Llanito on social media. Respondents perhaps deemed the informality and casual sentence construction of Llanito a more appropriate medium than formal English or Spanish to chat about local current events and share opinions about them on platforms such as Facebook and Twitter, or to interact with close friends or family on instant messaging services. A local Facebook group that has soared in popularity in recent years 'Speak Freely !!!' and other such groups might just be where contemporary Llanito gets documented in these times, perhaps more than ever before in the written history of the dialect.

While it is still early to predict the effects on Llanito of recent Brexit conversations, and of potential re-emergences of the Covid-19 virus forcing the population into further lockdowns, it is often through the movement of people (either migration into other communities or isolation from them) that minority language diffusion will either accelerate or decelerate ${ }^{11}$. Presently, it

\footnotetext{
${ }^{10}$ Chevasco, D., op. cit.
}

${ }^{11}$ Kerswill, P., "Migration and language", in Klaus Mattheier, Ulrich Ammon \& Peter Trudgill (eds.) Sociolinguistics / Soziolinguistik. An international bandbook of the science of language and society, 2nd ed. Vol 3. Berlin: DeGruyter. 2006. 
appears that the Brexit agreement on the cards would increase the flow of people in and out of Gibraltar, according to former UK Foreign Secretary Dominic Raab's Written Ministerial Statement:

Gibraltar's future relationship with the EU that will permit an absence of physical checks at the land border with Spain, and therefore ensure fluidity of movement of people and goods between Gibraltar and the EU. ${ }^{12}$

While this new reality might imply the greater diffusion of the Spanish language in Gibraltar, I would argue that it is likely to have the opposite effect. A greater access to all things Spanish may fuel the Gibraltarian urge to reaffirm Gibraltarian identity. This could be manifested linguistically by speaking either Llanito or British English in as many local environments as possible, to differentiate themselves from the Spanish EU citizen, who may have taken on a new political role in the territory. Hence, the future of Llanito remains unclear and the jury is out on how future Brexit negotiations will be greeted locally.

With regards to Covid-19, further lockdowns may have an effect contrary to the envisaged Brexit agreement, meaning the isolation of individuals and family units again. Taking data from the study, we can assume that many young adults in Gibraltar would speak Llanito to the immediate family members in lockdown with them. An inability to cross the land or air frontiers into Spain or the UK respectively, would perhaps further propagate the usage of the hybrid language. Albeit a far-fetched comparison, such lockdowns do, in a sense, replicate Gibraltar's post-WWII isolation from Spain (from 1969 to 1985) with a closed land frontier, which according to Kellermann ${ }^{13}$ and Levey $^{14}$, had a lasting effect on language usage in Gibraltar. Hopefully, the spread of the pandemic will slow down, and this hypothetical scenario will never again materialise.

\footnotetext{
${ }^{12}$ HM Government of Gibraltar Press Release, Chief Minister's Statement to Parliament On The New Year's Eve Framework Agreement January 15, 2021, 61/2021. Available at: https:// www.gibraltar.gov.gi/press-releases/chief-ministers-statement-to-parliament-on-the-newyears-eve-framework-agreement-612021-6604. 2021. (Accessed 29 September 2021).

${ }^{13}$ Kellermann, A., A New New English: Language, Politics, and Identity in Gibraltar, Heidelberg: Herstellung, 2001.

${ }^{14}$ Levey, D., op. cit.
} 


\section{THE FUTURE OF BILINGUALISM IN GIBRALTAR}

The categorisation in this study of Llanito as a language, different from Spanish, seems to have been welcomed by participants, who were able to distinguish situations in which Llanito would be the appropriate language form instead of Spanish. Nevertheless, as a code-switching form and a kind of vernacular solely used in Gibraltar, bilingualism being defined by one's proficiency speaking both English and Llanito would be of little academic or professional advantage on the global stage, away from Gibraltar's shores. For this reason, the term bilingualism in the study refers to proficiency in both English and Spanish.

It is significant that over $46 \%$ of those questioned do not believe future Gibraltarians would retain their English-Spanish bilingualism. The decline in the ability of young Gibraltarians to speak and write in Spanish is owed to the fact that formal Spanish proficiency is neither required for school, work, or most administrative duties in local society. Moreover, English is the language of technology, popular culture, travel, communications, and many other mediums that most young Gibraltarians would be interested in. While access to Spanish TV channels and radio stations can be had in Gibraltar due to the geographical proximity to Spain, in the case of TV channels, Spanish channels are eclipsed by the extensive availability of the UK Sky Satellite Network, which is arguably what young Gibraltarians generally choose to watch, if this has not been virtually replaced by content platforms like Netflix, Amazon Prime and other English-language providers. Regarding radio stations, despite basing this purely on personal experience, there may still be some considerable distribution of Spanish radio stations on the Rock, especially when driving around town.

Despite the link between language and identity mentioned above, the act of separating language from identity might be the key to maintaining bilingualism in Gibraltar. Contemporary refers to Pérez-Milans ${ }^{15}$ and how he depicts a modern world view of learning languages as equating to the gathering of professional skills for the international market, and not as symbols of ethnicity or nationality. From the data collected, the young Gibraltarian adults also seem to buy into this idea of language as currency. $80 \%$ of respondents

${ }^{15}$ Pérez-Milans, M., "Language and identity in linguistic ethnography", in S. Preece (ed) The Routledge Handbook of Language \& Identity, New York and London: Routledge, 2015. 
would welcome the introduction of a bilingual education system (English and Spanish) in Gibraltar to safeguard what appears to many to be the dying out of a truly bilingual Gibraltarian. This system would undoubtedly be the ideal modus operandi for a bilingual society in an age of political peace and good neighbourly relations, however, continuing discussions over the Brexit deal for Gibraltar may prove to be a spanner in the works of any such proposal. Neighbourly trust towards Spain's political intentions is very often tenuous, and prior to the Spanish General Elections of 2019, when the conservative Popular party ruled in Spain, the then foreign minister clearly stated that "the Spanish flag would be flying on top of the Rock after Brexit"16. Such assertions make Gibraltarians fear any movement closer to Spain, including possibly spreading the Spanish language.

As a counterargument, while Gibraltarians may be adamant about speaking in English and not giving up a single iota of their English-speaking identity, the resulting absence of the UK from the European Union may cause the English language to gradually lose its significance in the bloc. According to Kużelewska ${ }^{17}$, the fact that neither Malta nor Ireland have declared English their official language in the EU, coupled with France's former strong resistance to adopting English as the union's main working language, may result in French and German becoming the EU's working languages in the future. Kużelewska does however conclude that English is presently too widespread to envisage it losing its popularity any time soon.

Contemporary concludes that home and family life are the antidotes to the prospective monolingual English-speaking Gibraltarian. Even though Spanish is never given official status within the education system, were spoken Spanish to exist at some level within the home, or with certain family members, the chances of losing all bilingual proficiency would be mitigated. Hopeful that Covid-19 lockdowns are a thing of the past on both sides of the frontier, the final outcome of Brexit negotiations and its influence on local politics, sentiments and the community's willingness to communicate in the language codes at its disposal, will be Gibraltar's linguistic challenge moving forwards.

${ }^{16}$ LEE, G., "Brexit: End to Gibraltar land border prompts joy and trepidation". Available at: https://www.bbc.com/news/world-europe-55674148. 2021. (Accessed 29 September 2021).

${ }^{17}$ KużELwsKa, E., "Impact of Brexit on the status of the English language in the European Union”. Środkowoeuropejskie Studia Polityczne University of Bialystok, 2019. 


\section{BIBLIOGRAPHICAL REFERENCES}

ANCHIMBE, E. A., Structural and Sociolinguistic Perspectives on Indigenisation. Dordrecht: Springer Netherlands. 2014.

AUCKLE, T. and BARNES, L. "Code-Switching, Language Mixing and Fused Lects: Emerging Trends in Multilingual Mauritius”, Language Matters 42, 1, 2011: 104-25.

CHEVASCO, D., Contemporary Bilingualism, Llanito and Language Policy in Gibraltar: A Study, Universidad de Cádiz, 2019.

KELlERMANN, A., A New New English: Language, Politics, and Identity in Gibraltar, Heidelberg: Herstellung, 2001.

KERSWILL, P., "Migration and language", in Klaus Mattheier, Ulrich Ammon \& Peter Trudgill (eds.) Sociolinguistics / Soziolinguistik. An international handbook of the science of language and society, 2nd ed. Vol 3. Berlin: DeGruyter. 2006.

KUŻELWSKA, E., "Impact of Brexit on the status of the English language in the European Union". Środkowoeuropejskie Studia Polityczne University of Biatystok, 2019.

LEVEY, D., Language Change and Variation in Gibraltar, John Benjamins Publishing, 2008.

MAY, S., "Language Rights: Moving the Debate Forward", Journal of Sociolinguistics 9, 3, 2005: 319-47.

PEÑALVA, S. L., "An Ethnographic Portrait of Translingual/Transcultural Navigation among Immigrant Children and Youth: Voices during Sunday School at a Latino Church", Journal of Multilingual and Multicultural Development. 2016:1-15.

PÉREZ-MILANS, M., "Language and identity in linguistic ethnography", in S. Preece (ed) The Routledge Handbook of Language \& Identity, New York and London: Routledge, 2015.

SAYER, P., "Demystifying Language Mixing: Spanglish in School", Journal of Latinos and Education. 7, 2, 2008: 94-112. 


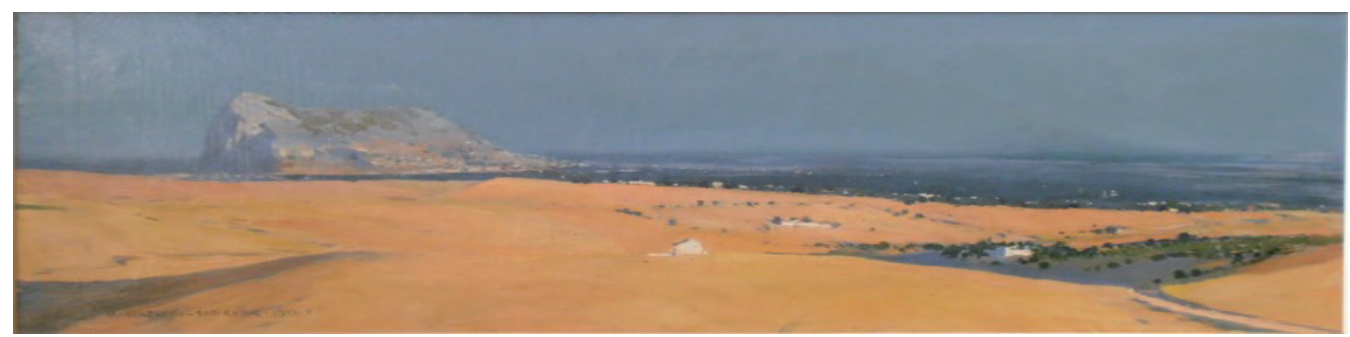

\section{Cuadernos de Gibraltar Gibraltar Reports}

\section{\#04 | 2020-2021}

Sumario

Table of Contents

\section{EDITORIAL}

Alejandro DEL VALLE GÁLVEZ; Inmaculada GONZÁLEZ GARCÍA, Gibraltar after the Brexit: Looking for a New and Imaginative Model of Cross-Border Cooperation in the EU Framework

\section{ESTUDIOS Y NOTAS}

Luis M. HINOJOSA MARTÍNEZ, Los movimientos de capital y los servicios financieros en las relaciones con Reino Unido y Gibraltar tras el Brexit: ¿Seguridad jurídica o ley de la selva?

Luis ROMERO BARTUMEUS, Las escalas de submarinos nucleares en Gibraltar y Rota, y los Planes de Emergencia Radiológica

Facundo D. RODRÍGUEZ, La cuestión de las Malvinas (Falklands) en el Cuarto Decenio Internacional para la Eliminación del Colonialismo

\section{ÁGORA}

Alejandro DEL VALLE GÁLVEZ, Creación de una AECT-Agrupación Europea de Cooperación Territorial- Campo de Gibraltar/Gibraltar (Guía breve sobre planteamiento, requisitos y procedimiento)

Alejandro GARCÍA HEREDIA, El Acuerdo Fiscal entre España y el Reino Unido en relación con Gibraltar

David CHEVASCO, Notes on Contemporary Bilingualism, Llanito and Language Policy in Gibraltar: a Study with a Present-day View of Linguistic Challenges

\section{DOCUMENTACIÓN}

Inmaculada GONZÁLEZ GARCÍA; Alejandro DEL VALLE GÁLVEZ; Lorena CALVO MARISCAL, Juan D. TORREJÓN RODRÍGUEZ:

Documentación I. Naciones Unidas - Gibraltar - Decisiones aprobadas por la Asamblea General de la ONU (2017-2019)

Documentación II. Brexit y Gibraltar - Tratado de Retirada, Protocolo, Tratado Fiscal y MOUs (2018-2020)

Documentación III. España, Brexit y Gibraltar. Declaraciones, Comunicados y Notas de Prensa (2018-2020)

Documentación IV. Andalucía, Brexit y Gibraltar (2018-2019)

Documentación V. Grupo Transfronterizo/Cross-Frontier Group, Memorándum de Entendimiento con el Gobierno de Gibraltar (2017) y Reglamento de Funcionamiento (2018)

Documentación VI. Principio de Acuerdo entre España y el Reino Unido sobre Gibraltar y sobre el Brexit, de 31.12.2020

Documentación VII. Mandato negociador para el Tratado entre el Reino Unido y la Unión Europea con respecto a Gibraltar, 5 de octubre de 2021

\section{LOS ARCHIVOS DE LUIS ROMERO BARTUMEUS}

La descolonización de Gibraltar, de CALVAR, J. - GUERITZ , E. J. - DEL CAMPO, S. - DAVIS H., Ed. Instituto de Cuestiones Internacionales, 1981, 110 páginas, por Luis ROMERO BARTUMEUS

Matar al Mensajero, Vivencias de un «Palomo» en Gibraltar, de TRIAY BOZZINO, J. J. - CASAUS BALAO, J. A., Ed. : Colecciones AUREA, 2000, 198 páginas, por Luis ROMERO BARTUMEUS

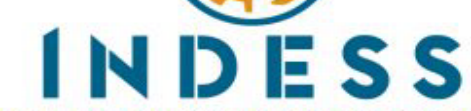

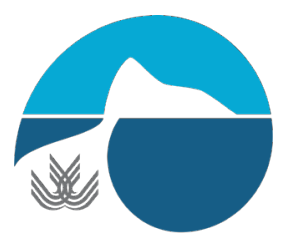

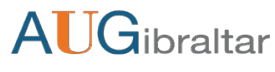

CÁTEDRA JEAN MONNET INMIGRACIÓN Y FRONTERAS DERECHO DE LA UNIÓN EUROPEA $\sim 2$

EDUCACIÓN DE LA UNIÓN EUROPEA

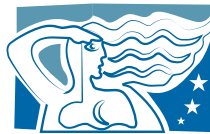

ESTUDIOS

INTERNACIONALES Y EUROPEOS

Centro de Estudios Internacionales y Europeos del Área del Estrecho 